\title{
Governments as owners: State-owned multinational companies
}

\author{
Alvaro Cuervo-Cazurra ${ }^{1}$, \\ Andrew Inkpen ${ }^{2}$, \\ Aldo Musacchio ${ }^{3}$ and \\ Kannan Ramaswamy ${ }^{2}$ \\ ${ }^{1}$ D'Amore-McKim School of Business, \\ Northeastern University, Boston, USA; \\ ${ }^{2}$ Thunderbird School of Global Management, \\ Glendale, USA; ${ }^{3}$ Harvard Business School; \\ Brandeis University, National Bureau of Economic \\ Research, Waltham, USA \\ Correspondence: \\ A Musacchio, Harvard Business School; \\ Brandeis University, National Bureau of \\ Economic Research, 415 South Street MS 032, \\ Waltham, MA 02453, USA. \\ email: aldom@brandeis.edu
}

\begin{abstract}
The globalization of state-owned multinational companies (SOMNCs) has become an important phenomenon in international business (IB), yet it has received scant attention in the literature. We explain how the analysis of SOMNCs can help advance the literature by extending our understanding of state-owned firms (SOEs) and multinational companies (MNCs) in at least two ways. First, we cross-fertilize the IB and SOEs literatures in their analysis of foreign investment behavior and introduce two arguments: the extraterritoriality argument, which helps explain how the MNC dimension of SOMNCs extends the SOE literature, and the non-business internationalization argument, which helps explain how the SOE dimension of SOMNCs extends the MNC literature. Second, we analyze how the study of SOMNCs can help develop new insights of theories of firm behavior. In this respect, we introduce five arguments: the triple agency conflict argument in agency theory; the owner risk argument in transaction costs economics; the advantage and disadvantage of ownership argument in the resource-based view (RBV); the power escape argument in resource dependence theory; and the illegitimate ownership argument in neoinstitutional theory. After our analysis, we introduce the papers in the special issue that, collectively, reflect diverse and sophisticated research interest in the topic of SOMNCs.

Journal of International Business Studies (2014) 45, 9|9-942. doi: I0. I 057/jibs.20 I4.43
\end{abstract}

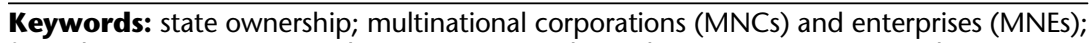
firm objectives; internationalization; resource dependency; transaction cost theory, transaction cost economics or transaction cost analysis

\section{INTRODUCTION}

The globalization of state-owned multinational companies (SOMNCs) and the wide variety of approaches taken by the state as a cross-border investor have become an important phenomenon. State-owned enterprises (SOEs) from emerging economies such as Brazil, China, India, Kuwait, Malaysia, Russia and Saudi Arabia, and from advanced economies such as France, Norway and South Korea, have extended their global reach (The Economist, 2012). While some of the SOEs in natural resource-based sectors, such as mining and oil and gas, had internationalized in the middle of the twentieth century, other SOEs - specializing in technology-based segments such as nuclear power generation, automobile manufacturing and telecommunication equipment or in services such as banking, transportation and construction - have only recently
Received: 28 January 2014

Revised: 19 May 2014

2nd Revision: 11 July 2014

Accepted: 12 July 2014

Online publication date: 21 August 2014 
expanded outside their domestic borders. By 2010, there were at least 650 SOMNCs with more than 8500 foreign affiliates, of which about $44 \%$ were from advanced economies. Even if such number of SOMNCs seems small compared to the over 100,000 MNCs in the world, SOMNCs are extremely large in size; in 2010 there were 19 SOMNCs among the 100 largest MNCs in the world (UNCTAD, 2011: 28). SOMNCs that appear among the 200 largest nonfinancial MNCs in the world had invested abroad US $\$ 1.8$ trillion (Sauvant \& Strauss, 2012). Foreign investments by Sovereign Wealth Funds (SWFs) have emerged as yet another vehicle for channeling state investments in the global arena (Sauvant, Sachs, \& Schmit Jongbloed, 2012). Taken together, the patterns of state investment abroad demand more focused research attention from international business (IB) scholars.

Despite the global expansion of SOMNCs, IB scholars' study of these firms has been limited (with notable early exceptions like Aharoni, 1986; Anastassopoulos, Blanc, \& Dussauge, 1987; Mazzolini, 1979; Vernon, 1979; and more recent studies like Buckley, Clegg, Cross, Liu, Voss, \& Zheng, 2007; Cui \& Jiang, 2012; Knutsen, Rygh, \& Hveem, 2011; Shapiro \& Globerman, 2012; and the papers in this special issue). This gap in the IB literature is perhaps due to the fact that the internationalization of SOMNCs on a massive scale is indeed a relatively new phenomenon. Given the usual domestic focus of SOEs, the globalization of these enterprises might not have been of sufficient interest to IB scholars in the past. Further, much of the extant literature in IB has tended to characterize governments and business as antagonists, bargaining over shares of rents in host country contexts, as illustrated by Vernon (1979) and Stopford, Strange, and Henley (1992), a perspective that might have unwittingly limited deeper interest in the internationalization of SOMNCs. Much of the received wisdom on SOEs has therefore originated in the public administration, developmental economics and political economy literatures. Although these fields have developed crucial insights into the forms and functions of SOEs, we know precious little about their international impacts and aspirations in the global arena.

To remedy this gap, in this paper we analyze how the study of SOMNCs can help extend the literature. We do this in two ways. First, we contend that the study of SOMNCs sits at an important crossroads between IB and political economy and that the two fields can benefit from a cross-fertilization of insights; IB phenomena in general are complex in nature and amenable to interdisciplinary approaches (Cheng,
Henisz, Roth, \& Swaminathan, 2009). Hence, we propose that the successful internationalization of some SOMNCs can help extend existing theoretical approaches and assumptions about the competitiveness and behavior of SOEs and their evolution into multinational companies (MNCs). We therefore introduce two arguments that reflect this cross-fertilization of the IB and SOE literatures. First, we propose the extraterritoriality argument, which explains how the MNC dimension of SOMNCs extends the SOE literature. Second, we introduce the non-business internationalization argument, which helps explain how the SOE dimension of SOMNCs extends the IB literature.

Second, we propose that the study of SOMNCs not only can extend our understanding of the topics of MNCs and SOEs via cross-fertilization but also can extend existing theories of the firm by taking into account some of the particularities of SOMNCs that traditional theoretical arguments have not considered in depth. Specifically, we explain how agency theory, transaction costs theory, the RBV, resource dependence theory and neo-institutional theory can be extended by taking into account the differing objectives of the state as an owner. We discuss how these differing objectives modify the predictions of the theories in the internationalization of the firm and introduce five arguments: the triple agency conflict argument to extend agency theory; the owner risk argument to extend transaction cost economics; the advantage and disadvantage of ownership argument to extend resource-based theory; the power escape argument to extend resource dependence; and the illegitimate ownership argument to extend neo-institutional theory.

We conclude this introduction with a review of the articles that compose this special issue, explaining how as a group they extend theory and provide a better understanding of the phenomenon of SOMNCs. The article serves as an integrative platform to help IB scholars address the core issues that dominate debates on the global role of SOEs, SWFs and state-sponsored foreign direct investment (FDI) sourcing agencies, which are collectively reshaping the impact of the state in global economic activity.

\section{THE CHANGING LANDSCAPE OF SOES}

The classical view of SOEs has typically been framed around dimensions of efficiency, productivity and administrative bureaucracy originating in the conflicting operational, financial and social objectives faced by these enterprises. Thus, much of the extant literature tends to view SOEs as inefficient, bureaucratic 
entities that are poorly managed without coherence in their strategy and resource allocation decisions, and that as a result they are less efficient in state than in private hands (see a review in Megginson \& Netter, 2001, and for a recent analysis see Arocena \& Oliveros, 2012; for a counter argument see Pryke, 1971). However, we contend that the time is ripe to revise this classical view because in many of the market economies, SOEs have undergone enormous change spurred mostly by the pro-market reforms that swept through Europe, Latin America and Asia. Although SOEs have existed for a long time, these changes have heralded the rise of a new breed of SOEs that have shed some of the shortcomings of their predecessors as they focus more intently on the global arena.

Hence, to provide a context for understanding the global behaviors of SOEs, we now present a brief discussion of the fundamental building blocks of established theory on state ownership, the rationale behind the emergence of SOEs and the contemporary changes that have redefined our understanding of these organizations. We acknowledge that there are differences across countries, industries, SOEs and managers, but for the sake of simplification we present now some general arguments.

\section{The Logic of SOEs}

There are two traditional explanations for the existence of SOEs: an economic one that centers on the solution of market imperfections and a political one that centers on the ideology and political strategy of government officials regarding the private ownership of particular productive assets. In practice, most governments use a mix of both to justify the creation of SOEs, but here we separate them for analytical purposes.

\section{Market imperfections}

In economics, state ownership of firms tends to be justified as one solution to market failures. When markets are unable to efficiently allocate products or resources to the most welfare-enhancing use, government officials are compelled to intervene to address these inefficiencies using an array of instruments such as taxation, regulation or direct ownership; the latter instrument results in the creation of SOEs (see Levy, 1987; Lindsay, 1976; and a review in Lawson, 1994). Market failures can take several forms: public goods, in which the rival and nonexcludable nature of their consumption will result in their depletion; positive externalities, in which the providers of the externalities are not compensated for this effect and thus will underprovide them to society; negative externalities, in which the generators of the externalities do not have to pay for these effects and thus will overprovide them to society; information asymmetries, which result in moral hazard and adverse selection problems; incomplete markets, in which consumers cannot obtain the products even if they are willing to pay their price; and natural monopolies, in which it is more efficient for society to have one provider than to have competition among several firms, and thus there is the danger of undersupply or overpricing.

A government can address market failures via several mechanisms (see a review in Laffont \& Tirole, 1993). It can tax behavior, either with direct subsidies to promote the behavior or with additional taxes to discourage it. It can regulate behavior by limiting the actions of companies or mandating that companies take certain actions. It can also choose to be the provider of the goods to society. This third mechanism may result in the creation of SOEs, as the government may choose to supply the good directly instead of via an SOE. The selection of the best option among the mechanisms is rarely clear-cut and will depend on the complexity of the market failure as well as the ability of the state apparatus to monitor and implement the mechanism. Governments suffer from government failures (Le Grand, 1991), which can take the form of state capture, lack of technical capacity to run firms and crowding out, ultimately limiting their ability to effectively manage SOEs.

\section{Ideologies and political strategies}

An alternative to the market failure explanation takes a political point of view and explains the existence of SOEs as a result of the ideology and the political strategy of government officials regarding private ownership of particular productive assets. ${ }^{1}$ We can distinguish four types of economic ideologies or political strategies that, despite their differences, all result in the creation of SOEs ${ }^{2}$ : communism, nationalism, social and strategic. First is the economic communist ${ }^{3}$ ideology, which justifies the creation of SOEs and the nationalization of private firms as a response to the accumulation of wealth in the hands of private owners at the expense of workers and the need for the government to address this injustice, as delineated by Marx (1906) and Marx and Engels (1893). Under this view, citizens are the rightful owners of companies and land, and the state becomes the de-facto owner of companies in the name of the citizens of the country. A milder version is socialism, which induces the creation of SOEs alongside the 
regulation of private enterprise. Second is the economic nationalist ideology, which argues that the government needs to create SOEs to speed up the development of the country and address the inability of private enterprise to achieve this. An alternative political strategy, which can or cannot be sustained by a nationalist ideology, relies on import substitution models of development (Bruton, 1998) or the need for the government to control the "commanding heights" (i.e., that is firms with important backward and forward linkages) (Jones \& Mason, 1982; Rodrick, 2007). According to the import substitution approach, the logic of government intervention is a mixture of a desire to reduce dependence on imports and foreign companies, and a desire to reduce the power of the private owners in industry (Cardoso \& Faletto, 1979; Prebisch, 1959; Vernon, 1979). The commanding heights view is based on the idea that local entrepreneurs did not have the capacity, interest or foresight to invest in the development of large-scale projects with important forward and backward linkages and that were, therefore, necessary for the industrialization of the country. Local firms sold their output in a protected market and both nationalization and the creation of SOEs filled in the void left by private entrepreneurs. Third is an economic social ideology that proposes that the government needs to invest in SOEs to facilitate the achievement of socially desirable objectives, such as education, health care, or poverty reduction. In such cases, the political strategy of the government promoted redistribution and questioned the ability of private entrepreneurs to achieve social objectives. Fourth is the economic strategic ideology that justifies the creation of SOEs as being strategic for the country, such as defense. The definition of which industries have strategic merit and require SOEs varies across countries based on the particular perspectives and political strategies of governments and politicians.

\section{A Typology of SOEs}

While many of the SOEs across the globe share founding objectives that indeed converge around the need to alleviate market imperfections, foster investment in social welfare sectors or generate employment at home, these organizational forms have witnessed significant transformations as many have emerged to become MNCs in their own right. The historical perception of SOEs is rooted in the view that these organizational forms were solely created by state capital, managed by political appointees and chartered to serve the collective good of the country at large (Ramaswamy, Kroeck, \& Renforth, 1996; Ramaswamy, 2001; Shleifer \& Vishny, 1998). SOEs such as the Russian oil and gas firm Gazprom, the Mexican oil firm Pemex or the Indian engineering firm BHEL are examples of such entities that once typified this genre. As a result, many of these SOEs confined their operations to their home countries and usually internationalized via exports, especially of raw materials or energy products, to provide foreign exchange to the home governments (Aharoni, 1986; Anastassopoulos et al., 1987; Vernon, 1979).

As many capitalist and mixed economies embraced pro-market reforms, and the centrally directed economic structures of the communist countries fell apart in the last quarter of the twentieth century (Yergin \& Stanislaw, 1998), many prototypical SOEs were radically redesigned. The privatization processes of the late twentieth century resulted in a reduction in SOE numbers, through full privatization of many such firms, and in the transformation of others into partially privatized firms. As SOEs became minority state owned or fully private, their managerial behavior changed (see Inoue, Lazzarini, \& Musacchio, 2013; Ramaswamy, 2001 and Ramaswamy and von Glinow, 2000 for a discussion of some of these changes in the Indian context). In many instances governments privatized control and kept minority stakes with so-called "golden shares," which gave them veto rights over major decisions such as mergers and acquisitions. These privatization processes resulted in a large interest in the literature that tended to justify their privatization by arguing that SOEs were less efficient than private companies (see reviews in Megginson \& Netter, 2001; Vickers \& Yarrow, 1988). However, the privatization processes did not spell the end of state ownership of companies. Instead they marked the beginning of a new range of organizations that represent innovative hybrids of state and private capital, spanning both local and foreign domains, more likely viewed as vehicles for the state to exercise its foreign policy and diplomacy goals alongside conventional social and financial objectives. While some firms became fully independent private companies or were sold to private investors, in many other cases governments kept a portion of the equity in the privatized firms or kept control of such firms, sharing ownership with a variety of institutional and individual investors via joint ventures or via partial sales in the stock market. Additionally, some governments maintained majority and minority equity positions in firms through 
holding companies, state-owned pension funds, development banks or SWFs (Musacchio \& Lazzarini, 2014). Other SOEs simply went out of business and their assets were sold.

At the same time, reductions in trade and investment barriers coupled with advances in transportation and communication technologies facilitated the transformation of many remaining SOEs into SOMNCs, with SOEs redirecting their attention to the global economy and investing outside their countries. Notwithstanding the earlier expansions across borders by SOEs in the oil industry, SOMNCs emerged as an important and little understood force in the global economy, leading to a renewed interest in these firms, both in the popular press (The Economist, 2012) and in academic analyses (Buckley et al., 2007; Cui \& Jiang, 2012; Gerard, 2007; Knutsen et al., 2011; Musacchio \& Lazzarini, 2014; Shapiro \& Globerman, 2012).

To clarify the analysis, in Table 1 we introduce a typology of organizations under government ownership based on three criteria. The first criterion is the legal existence of the firm. We distinguish between state agencies that behave like companies but are not legally separate from the state and have budgets that are part of the national budget, from those that are legally separate companies with their own budgets. Thus, SOEs can be viewed as enterprises that produce and sell goods and services, as opposed to government entities in charge of providing public services such as health care, education or security (Aharoni, 1986). ${ }^{4}$ The provision of public services can be done by either SOEs or state agencies. The second criterion deals with how state ownership is exercised: directly via the control of firm shares by the state or indirectly via the control of shares by state-owned entities, such as SWFs, state-owned pension funds or convertible loans from state-owned banks. The third criterion is the degree of state ownership in the firm. Here we can separate state ownership into three types: fully owned, when the government owns all of the shares of the firm; majority owned, when the government own most of the shares of the firm; and minority owned, when the government owns less than the majority of the shares of the firm; one particular type of minority ownership is a golden share controlled firm, when the government only owns one share that grants it veto power over major strategic decisions such as mergers and acquisitions or foreign control. Hence, we define SOEs as legally independent firms with direct ownership by the state.

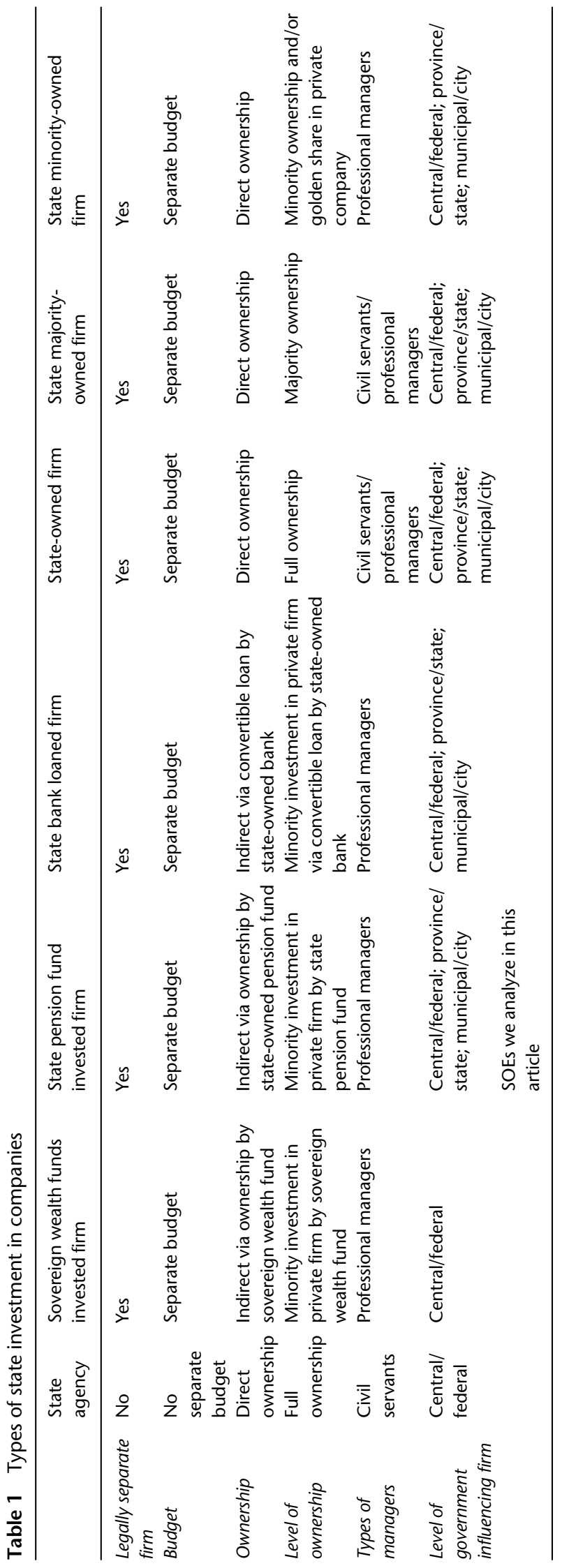


Although we classify SOEs by their level of ownership, the analysis of control in SOEs requires additional care because the traditional one-share, onevote rule that governs voting rights may not be as effective in the case of SOEs. Although we implicitly equate ownership control with operating control, we recognize that these two dimensions need not necessarily vary in step with each other. We use the concept of effective ownership to underscore that it is an amalgam of both the level of ownership as well as the means to exercise control over the entity (e.g., through golden shares or voting rights provisions). It is possible that the government can exercise significant operating control over the SOE even though it might own a relatively smaller share of the company. The government can operate not only as owner of the SOE but also as regulator and referee for SOE activities. Regulations can be applied in the government's favor and at the expense of other shareholders. Thus, even with a minority stake in a firm, and with larger private shareholders or even with the SOE being quoted on foreign exchanges, the government can exercise an influence far above the proportion of equity it holds. For example, in 2009 the Brazilian government, as a minority shareholder, allied with the pension funds of SOEs and banks to create a block of shareholders powerful enough to oust the CEO of the Brazilian mining firm Vale and to steer the company to invest in steel mills (Musacchio \& Lazzarini, 2014). Alternatively, it can also be the case that even in majority-owned firms politicians decide to appoint professional managers to run the SOE and give them autonomy on business decisions, not interfering on the actions taken by the firm. Thus, specific predictions regarding expected behavior need to be qualified by the particular characteristics of the SOE and its governance structure.

This classification is important not only for clarifying the multiple ways in which the government may own firms, but also for understanding patterns of their potential internationalization strategies. Building on the classification system we have presented above, and notwithstanding particular governance structures of specific SOEs, we propose that the most likely types of SOEs that would seek to internationalize would be the ones that are effectively wholly owned or majority owned by the state. In these firms both government officials and SOE managers have the incentive to internationalize the firm, although possibly for conflicting reasons: SOE managers may seek international markets to strengthen and grow the firm, while government officials may be focused on international political objectives independent of
SOE competitive outcomes. As the state dilutes its effective ownership and influence over firms, we would expect to find firms following strategies and actions that are more likely to focus on financial performance over any other social or political objectives. Hence, fully owned and majority-owned firms are more likely to pursue non-business objectives than minority-owned firms because external shareholders act as a counterbalance to the imposition of non-business objectives in the firm. Nevertheless, these firms will not function fully as private firms since the government may still exert influence over them. For instance, when the government holds only a golden share, it can block crucial internationalization efforts perceived as detrimental to its interests even though such efforts might be deemed profitable by shareholders.

In contrast to SOEs, firms that are indirectly owned by the government via SWFs, state pension funds or state banks are likely to follow similar behaviors to private firms in their internationalization because the government has a limited ability to direct their behavior; the government is not a direct owner. In fact, it is possible that these firms may even have advantages over private firms to internationalize as they may have access to subsidized capital from the government that they can use to purchase subsidiaries or open new operations abroad. Moreover, these firms are likely to be more focused on achieving high levels of performance than other stateowned firms (SOEs) because the government intermediaries have the mandate to achieve a return on their investments. For instance, SWFs need to ensure the future wealth of the country; state-owned pension funds need to ensure the future payment of pensions; and state-owned banks need to ensure the repayment of loans. As a result, these shareholders are more likely to demand that the company achieve superior performance than what would be expected of firms that are directly owned and controlled by the government. Finally, state agencies are not likely to engage in international markets because, as they are not independent companies, they are not able to contract independently from the state. At most they may be able to import to supply their operations.

While the classification suggested here attempts to capture most of the broad themes that drive finer differences across a broad range of SOEs, alternative classification schemes may well be able to provide additional insights. For example, drawing on the notion of multiple, different recipes (Rodrik, 2007), one could argue that the origins of the SOE (i.e., whether the enterprise was a de novo creation by the 
government, or a product of nationalization of an existing enterprise) have different implications for the internationalization pathways and aspirations that characterize the SOE. Further, the ownership roots of the SOE enterprise, whether the SOEs originated in the nationalization of domestic privately owned firms or the nationalization of foreign-owned enterprises, have an important bearing on subsequent internationalization choices. For example, in the oil industry, a cursory juxtaposition of the Russian SOE Gazprom and the Saudi SOE Saudi Aramco, which was originally founded as the US-based California-Arabian Standard Oil Company and later nationalized, illustrates the insights that can emerge from such classification. Gazprom has been a very ardent proponent of global expansion, partly propelled by its history and founding, the political currents in the country, and its preeminent position as a generator of foreign exchange for the treasury. In contrast, Saudi Aramco has been a reluctant globalizer, being more active in setting up and managing joint ventures to extend its own value creation opportunities at home. Having benefited from its origins as a foreign-owned company, it enjoyed a head start with respect to technology, standard process and procedures, and management systems, all areas of weakness among its many SOE peers elsewhere. These advantages accruing from its ownership heritage have allowed the company the luxury of a better planned internalization effort, unlike its peers that have been forced to go overseas to secure technology inputs among other resources.

Having developed a typology of internationalization behavior across different types of SOEs, we believe that the foundation has been laid for integrating disparate streams of research in the fields of SOEs and IB.

\section{SOMNCS AS A LABORATORY FOR EXTENDING THEORY}

We define an SOMNC as a legally independent firm with direct ownership by the state that has valueadding activities outside its home country. These value-added activities can be downstream activities such as production facilities or sales subsidiaries, as tend to be assumed when one thinks about a multinational company, or upstream activities such as purchasing subsidiaries or design or R\&D centers. Although SOEs vary in their level of ownership from full to majority to minority, in order to simplify the discussion we do not dwell on the differences among levels of ownership.
Table 2 provides a snapshot of the largest SOMNCs by foreign assets in 2010. This is a limited list of the largest firms because there is no readily available ranking of the largest SOMNCs akin to the Fortune Global 500 or Forbes Global 2000 rankings of publicly traded firms. SOMNCs were extremely large firms and, contrary to the view of SOEs in the privatization literature, they were actually profitable and highly internationalized, with an average of $46 \%$ of revenues coming from foreign operations. An additional way to gauge the importance of SOMNCs is to look at the Fortune Global 500 list of largest firms by revenues. Of the Top 100 firms in 2012, 27 are SOEs and 23 are SOMNCs. The 23 SOMNCs among the 100 largest firms in the world seem to be relatively profitable firms, with an average ROA of $3.44 \%$ and an operating margin of $14 \%$. Using data from Fortune Global 500 and S\&P, Capital IQ, their performance seems more impressive if we consider that the top 73 private firms in the world have an average ROA and operating margin of 3.19 and $5.7 \%$, respectively.

We now discuss two alternative approaches for extending theory using SOMNCs as a laboratory. The first one takes an interdisciplinary approach and combines insights from alternative streams of literature to enrich the insights of existing arguments. The second one uses a single theory approach and uses the setting of SOMNCs to extend the traditional arguments of the theory and accommodate some of the particularities of SOMNCs. These two approaches are reflected in the papers that compose this special issue, with some incorporating insights from different literatures to explain the behavior of SOMNCs while others extend one theory by analyzing SOMNCs.

\section{SOMNCs: Extending the Literatures on SOEs and MNCs}

Although there are clear logics that explain the existence of SOEs, the logics that explain the internationalization of these firms and their transformation into SOMNCs is less obvious. The study of SOMNCs can extend our understanding of the SOE literature using insights from the MNC literature and also extend our comprehension of the MNC literature by using insight from the SOE literature. This reiterates the value of an interdisciplinary approach for analyzing complex phenomena (Cheng et al., 2009). The result is two arguments that can be analyzed in more depth and tested in future studies: the extraterritoriality argument and the non-business internationalization argument. Table 3 summarizes them. One clarification is that these arguments focus on 
Table 2 Largest Non-Financial SOMNCs in 2010 ranked by Foreign Assets

\begin{tabular}{|c|c|c|c|c|c|c|c|}
\hline SOMNC & Economy & Industry & $\begin{array}{l}\text { Total assets } \\
\text { ( } \$ \text { millions) }\end{array}$ & $\begin{array}{l}\text { Percentage of } \\
\text { foreign assets }\end{array}$ & $\begin{array}{c}\text { Total revenues } \\
\text { (\$ millions) }\end{array}$ & $\begin{array}{l}\text { Foreign revenues } \\
\text { (as a percentage of } \\
\text { total sales) }\end{array}$ & $\begin{array}{c}\text { Home government } \\
\text { ownership } \\
\text { stake (as a percentage of } \\
\text { voting equity) }^{\mathrm{a}}\end{array}$ \\
\hline \multicolumn{8}{|l|}{$\begin{array}{l}\text { Government as a majority } \\
\text { shareholder }\end{array}$} \\
\hline Électricité de France & France & Utilities & 321,431 & 51 & 86,311 & $39 \%$ & 84.51 \\
\hline Vattenfall $A B$ & Sweden & Electricity, gas and water & 80,694 & 67 & 29,632 & $76 \%$ & 100.00 \\
\hline Statoil AS & Norway & Natural resources & 109,728 & 46 & 87,144 & $22 \%$ & 67.00 \\
\hline CITIC & China & Diversified & 315,433 & 14 & 30,605 & $36 \%$ & 100.00 \\
\hline Petroliam Nasional Berhad & Malaysia & Natural resources & 145,099 & 27 & 76,822 & $45 \%$ & 100.00 \\
\hline \multicolumn{8}{|l|}{ (Petronas) } \\
\hline Japan Tobacco Inc. & Japan & Food/processing & 43,108 & 73 & 72,273 & $43 \%$ & 50.00 \\
\hline China Ocean Shipping & China & $\begin{array}{l}\text { Transportation, shipping and } \\
\text { storage }\end{array}$ & 36,287 & 77 & 27,908 & $66 \%$ & 100.00 \\
\hline Singapore & Singapore & Telecommunications & 27,151 & 83 & 11,814 & $64 \%$ & 54.46 \\
\hline \multicolumn{8}{|l|}{ Telecommunications Ltd. } \\
\hline Qatar Telecom & Qatar & Telecommunications & 23,335 & 79 & 6600 & $77 \%$ & 55.00 \\
\hline Petroleo Brasileiro SA & Brazil & Natural resources & 200,270 & 7 & 115,892 & $25 \%$ & 66.00 \\
\hline Abu Dhabi National Energy & UAE & Utilities & 25,009 & 57 & 4590 & $67 \%$ & 100.00 \\
\hline \multicolumn{8}{|l|}{ Company } \\
\hline Petróleos de Venezuela SA & Venezuela & Natural resources & 149,601 & 8 & 74,996 & $43 \%$ & 100.00 \\
\hline China National Petroleum & China & Natural resources & 325,327 & 4 & 178,343 & $3 \%$ & 100.00 \\
\hline Oil and Natural Gas & India & Natural resources & 37,223 & 28 & 21,445 & $14 \%$ & 74.14 \\
\hline \multicolumn{8}{|l|}{ Corporation } \\
\hline DP World Limited & UAE & Transport and storage & 18,961 & 49 & 2929 & $40 \%$ & $80.45^{b}$ \\
\hline Axiata & Malaysia & Telecommunications & 10,847 & 83 & 3719 & $52 \%$ & 97.72 \\
\hline Sinochem Group & China & Natural resources & 25,132 & 32 & 35,577 & $77 \%$ & 100.00 \\
\hline China Resources Enterprises & HK/China & Natural resources & 9731 & 80 & 8273 & $89 \%$ & 51.38 \\
\hline China National Offshore Oil & China & Natural resources & 75,913 & 9 & 30,680 & $16 \%$ & 100.00 \\
\hline \multicolumn{8}{|c|}{ Corp. } \\
\hline Sime Darby Berhad & Malaysia & Diversified & 10,061 & 43 & 8827 & $69 \%$ & 51.93 \\
\hline China Railway Construction & China & Construction & 41,444 & 9 & 50,501 & $6 \%$ & 100.00 \\
\hline \multicolumn{8}{|c|}{ Corporation } \\
\hline China Minmetals Corp. & China & Natural resources & 18,889 & 12 & 24,956 & $16 \%$ & 100.00 \\
\hline Neptune Orient Lines Ltd. & Singapore & Transportation and storage & 5341 & 41 & 6516 & $75 \%$ & 68.00 \\
\hline
\end{tabular}


Government as a minority

shareholder

GDF Suez

EnelSpA

Eni Group

Deutsche Telekom AC

Eads

General Motors

France Telecom

Veolia Environnement SA

Germany
France
Italy

Automobile

Utilities

266,426

224,548

Italy

176,189

170,780

Natural resources

111,153

$63 \quad 168,046$

111,891

95,289

130,494

82,677

60,599

Germany

Defense

Netherlands

$\begin{array}{lll}\text { USA } & \text { Automobile } & 138,898\end{array}$

France

Telecommunications

125,970

135,592

60,269

46,075

46,481

$\begin{array}{lr}\text { Mining } & 68,829 \\ & 129,139\end{array}$

129,139
50,458

68,187

$56 \%$

30.30

32.00

Brazil

Deutsche Post

Germany

Transportation, shipping and storage

Renault

TeliaSonera AB

France

Zain

Tata Steel Ltd.

Sweden

Automobile

93,676

Telecommunications

37,342

51,617

14,788

$90 \%$

$22.40^{c}$

Kuwait

Telecommunications

19,863

India

Metal and metal products

24,419

South Africa Telecommunications $\quad 21,170$

Singapore

Construction and real estate

21,495

First Pacific Company

Limited

Sasol Limited

HK/China

Electrical and electronic

9397

equipment

Steinhoff International

Holdings

Sappi Limited

Lenovo Group

South Africa Chen

South Africa Diversified

18,977

7194

70

South Africa Wood and paper products

7297

Electrical and electronic

8956

66

66
44

$42 \%$

32.00

VimpelCom

Russian Telecommunications

15,725

24

21,580

13,344

2033

3926

$41 \%$

26.97

13.74

$39.70^{\mathrm{d}}$

30.50

17.86

37.30

49.20

15.74

17.63

40.90

10.37

21,676

$30.00^{\mathrm{e}}$

5636

14.89

5369

11.90

16,605

$42.00^{f}$

Federation

Agility Public Warehousing Kuwait

Construction and real estate

6221

10,117

$36.36^{\mathrm{g}}$

15.00

Company

ZTE Corporation

China

Telecommunications and

10,173

54

5976

$58 \%$

32.45

manufacturing

TPV Technology Limited

China

Wholesale trade

4155

64

8032

$70 \%$

35.06

Sources: Created with data in Sauvant and Strauss (2012) and Musacchio and Lazzarini (2014), Tables 2-7 and Figures 1-9.

Notes: ${ }^{2}$ Most of the ownership stakes represent the percentage of voting equity the government controls; in other instances the figures represent a percentage of total capital, depending on availability. ${ }^{\mathrm{b}}$ Owned by the Government of Dubai.

'SOGEADE is controlled by SOGEPA, a wholly owned SOE under the control of the French government.

${ }^{\mathrm{d}}$ The Government of Brazil controls only $6.9 \%$ of equity in Vale, through its investment arm BNDESPAR. However, the firm that controls Vale with $53.9 \%$ of voting shares, Valepar, is controlled by BNDESPAR (21.2\%) and Litel (49\%), which in turn are controlled by a consortia of pension funds from SOEs. See Musacchio and Lazzarini (2014), Chapter 9.

e Out of which $13.3 \%$ is held by the Government Employees Pension Fund.

${ }^{f}$ The Chinese government holds $36 \%$ of Legend Holdings, the controlling shareholder of Lenovo.

${ }^{9}$ Shares held by Telenor, a telecommunications company controlled by the Government of Norway. 

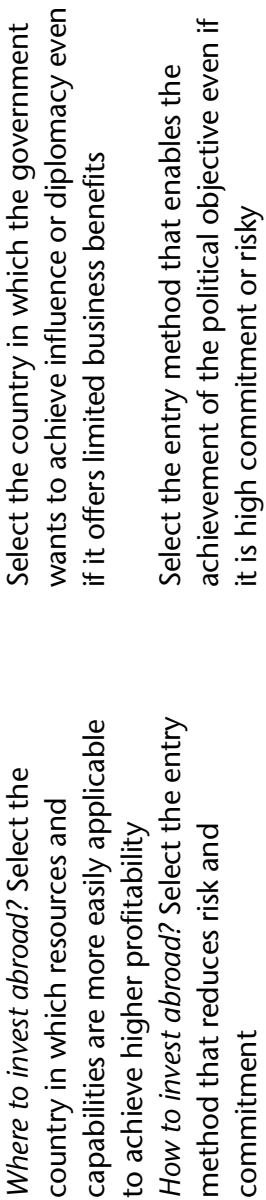

SOMNCs as a particular type of MNCs by their ownership; there are many actions and behaviors in which SOMNCs behave similarly to private MNCs, which we do not discuss as they do not highlight the uniqueness of SOMNCs.

The extraterritoriality argument: How the MNC dimension of SOMNCs extends the SOE literature

The twin logics of the existence of SOEs (market imperfections and ideology/political strategy) work well in a domestic setting, where the government has the right to impose rules and regulations and the incentive to promote citizens' welfare. However, SOMNCs' foreign investments pose a dilemma to these logics because such investments are made in locations outside the territory in which the home government can pass laws and regulations, which questions the premise that the government acts to help its citizens. We call this the extraterritoriality argument.

The multinationality dimension of the SOMNC requires us to rethink the existence of market imperfections in the home country as the logic for SOEs and consider extraterritorial market imperfections, in addition to traditional factor and market imperfections that drive both private and SOEs to internationalize as we discuss below. The standard market imperfection logic of the SOE solving market imperfections at home to support the well-being of its citizens is less applicable when the SOMNC invests abroad. When the SOE invests abroad, the government is, in effect, increasing the welfare of citizens of another country by addressing market imperfections there, replacing the host country government as the solver of such imperfections. This requires an extraterritorial view of the government owning firms to address market imperfections. Moreover, a common government view about FDI by domestic companies is that such investments are detrimental to the home country because they are made at the expense of domestic investment and taxes (Dutton, 1982; Joint Committee on Taxation, 1991; Stevens \& Lipsey, 1992). Therefore, the government should not encourage FDI by domestic firms (e.g., Feldstein, 1994), although this view that FDI is undertaken at the expense of domestic investment has been challenged (Desai, Foley, \& Hines, 2005). One can view market imperfections in a global context, especially in the case of global public goods, that require extraterritorial state ownership to ensure the protection of such global public goods and the solutions of these global market imperfections (Kaul, Grunberg, \& Stern, 1999). This idea 
would lead to the existence of firms owned by multiple governments rather than one. It is not clear why one particular government would assume the responsibility for solving global market imperfections via ownership when other governments are reaping the benefits. However, depending on the size of the imperfection and how it affects citizens at home, governments of large countries may decide to address the global market imperfections by themselves without waiting for other governments to contribute to the solution. Alternatively, there may be market imperfections across borders that limit the welfare of citizens at home and induce the government to invest abroad to reduce them, such as ensuring the adequate supply of products or services by foreign providers when there are incomplete markets.

One clarification here is that this argument differs from the expansion of a SOMNC to address transaction costs that exist across borders in the factor or product markets and that induce firms to become MNCs to ensure the supply of key raw materials or factors of production or the access to key markets; this is one of the traditional explanations for the existence of MNCs (Buckley \& Casson, 1976; Teece, 1977). In some cases, such as in natural resourcebased industries, SOMNCs make investments overseas to reduce transaction costs. For example, the Venezuelan state-owned petroleum company PDVSA found it beneficial to monetize its heavy crude by building refining capacity in the United States, its key market. Since the crude was of a grade that could not be easily refined at home, this move was seen as a logical attempt to generate revenues for the Venezuelan government that would not have accrued otherwise. The project generated employment for workers in the host country and possibly contributed tax revenues to the host government, and these host country outcomes are difficult to justify under the logic of a government owning firms to solve market imperfections faced by its citizens. Similar moves have been undertaken by a host of other SOMNCs in petroleum, such as Gazprom (Ramaswamy, 2013), Kuwait Petroleum Corporation and Rosneft to name a few (Gustafson, 2012). These foreign expansions are similar to those made by private oil and gas firms, which locate refineries near consumption markets to reduce transaction costs, and thus are not specific drivers of the expansion of SOMNCs.

The ideological/political strategy explanation of the existence of SOEs can be extended with the analysis of SOMNCs. Politicians in a country, especially those who are democratically elected, have the ability and right to pass laws in line with their ideology and can decide to have SOEs in the economy. However, direct foreign investments by SOEs add an extraterritorial dimension to the ideology logic, with the government of one country imposing its ideology toward SOEs in the economy of another government. Thus, SOEs could become an indirect extraterritoriality mechanism to transfer an ideology or policy predilection of high intervention in the economy. This extraterritoriality depends, of course, on the relative size of the home and host countries, with governments of larger home countries being more able to impose their ideologies and political preferences via their SOEs on governments of smaller countries because they can exercise more political and economic clout to support their SOMNCs.

We propose that the use of SOEs to implement ideologies and political strategies has different impacts depending on the particular ideology or political strategy followed. In the case of governments following an economic communist ideology, the use of SOMNCs may be in line with the logic of replacing private with state ownership for means of production, with SOMNCs doing so in another country. Although the communist logic-induced governments to directly impose it via invasion or supporting a revolution, a milder instrument could be the use of SOMNCs as a means of transferring a communist ideology. However, such investments may clash with host governments that follow a different ideology, and the host government may resort to blocking investments with such objectives (Globerman \& Shapiro, 2009). In contrast, if the home government has an economic nationalism ideology, promoting SOMNCs may not conflict with the desires of the host government. Inducing SOEs to invest abroad can be done to obtain raw materials needed for the home country or to reduce the dependence of the home country on imports by private companies. Economic nationalism does not carry the desire to impose the ideology in the host country. Rather, it can be achieved when the host country does not have an economic nationalistic ideology that would induce it to limit control by foreign firms.

\section{The non-business internationalization argument: How the SOE dimension of SOMNCs extends the MNC literature}

The existence of SOMNCs can help extend the logic of MNCs discussed in the IB literature. This literature tends to assume profit-maximizing private companies becoming multinationals to increase their profitability as they seek markets, natural resources, strategic assets or efficiency (Dunning, 1993). 
MNCs are induced to invest abroad by intrinsic and extrinsic drivers (Van Tulder, Lem, \& Geleynse, 2013). Even if some SOMNC investments may be made with the profitability and market-seeking motives in mind akin to those pursued by private MNCs, in some occasions the governments that own or control the firms may, alternatively, induce them to invest abroad to achieve political rather than profitability objectives. Thus, unlike MNCs that measure the success of foreign investments based on their contribution to firm profitability metrics such as return on investment, in SOMNCs the existence of multiple and possibly conflicting demands from citizens, politicians and managers complicates the definition of success and thus the actions that are taken to achieve such success.

We call this the non-business internationalization argument and explain it by analyzing the sequence of decisions a manager has to undertake when considering internationalizing the firm: the decision to internationalize, the selection of the country in which to internationalize and the selection of the method of entry.

The internationalization decision at its core represents a trade-off between the benefits of accessing a wider market for the firm's products and services or gaining new sources of competitive advantage that can be deployed elsewhere, and the costs incurred to capture such benefits (Hymer, 1976). Although this conceptualization is logical and widely accepted among companies that are founded on private capital, it tends to break down when applied to an examination of SOMNCs' motivations to internationalize because it does not account for non-valueadding objectives or, at the extreme, even valuedestroying motives. Although SOMCs may behave like private firms in their internationalization, in many occasions SOMNCs may internationalize to achieve political or economic security objectives that have little to do with the business of the firm or performance gains, such as facilitating political relationships between countries, obtaining foreign exchange for the home country, or improving the sphere of influence exercised by the home country government. For example, the Russian state-owned gas company Gazprom moved to consolidate its position among the COMECON countries and the Central Asian Republics, many of which were originally aligned with the Soviet Union before its collapse. This was seen mostly as a blocking strategy that would prevent Western powers from forming lucrative alliances with these countries that would diminish Russian influence.
Having decided to internationalize, the next step entails the choice of a particular country in which to invest. Traditionally, the firm selects the country in which its resources and capabilities can more easily be transferred and used, achieving higher profitability from resources and capabilities it has already developed. Alternatively, it will select a country in which it can obtain resources and capabilities that are better than those available in the home country, to increase the profitability of its operations (Dunning, 1993). In the realm of SOMNCs, at times the choice of investment location might not be quite so driven by profitability. Reasons such as realizing the foreign policy aims of the home government or expanding its zone of influence among global peers might be deemed more valuable than merely capturing competitive benefits or leveraging comparative factor cost advantages. For example, some of the Chinese SOMNCs in the infrastructure and mining sectors have arguably targeted markets in the African continent as a means of increasing Chinese government influence there and support relationships between the Chinese and local governments.

Once the location for the foreign investment has been determined, the focus shifts to identifying the appropriate mode of entry and the type of operations the firm establishes (see a review in Datta, Herrmann, \& Rasheed, 2002, and a criticism in Shaver, 2013). Traditional models argue that the firm selects the entry mode that enables it to reduce risks and exposure in the country or that facilitates obtaining resources needed to operate efficiently there (Johanson \& Vahlne, 1977). A wealth of literature in transactions cost economics has yielded significant insights into factors that help an organization choose between various forms of entry ranging from licensing to joint ventures and alliances (Anderson \& Gatignon, 1986). Much of the received wisdom in this regard focuses on observable criteria that have clear economic implications. In contrast, SOMNCs may select modes of entry and operations that enable them to achieve the political objective of the government even if such methods and operations are risky or require large commitments to the country and do not enable the firms to achieve profitability. The mode of entry decision may very well be a product of political calculation rather than economic consideration. For example, the Indian oil and gas company ONGC floated a foreign arm solely to bid for overseas resources as a means of securing the country's energy future. Many of the acquisitions came at very high prices that were economically disadvantageous. The government nevertheless 
chose to pursue such opportunities solely to ensure energy security, an objective that would not have been captured in the cost vs benefits calculus of prevailing models of internationalization.

In summary, we contend that the very nature of ownership and control among SOEs presents a markedly different set of parameters that SOMNCs have to address as they contemplate their globalization strategies. Unlike their private sector counterparts, where the decisions are largely driven by the business objectives underlying the creation of economic value, and which a few SOMCs that enjoy managerial autonomy and constraints on government interferences may follow, many SOMNCs have to factor in the political goals and non-business motivations of their state owners. As a result, they may be more constrained than their private sector peers in all aspects of their internationalization efforts, spanning the entire range of decisions from the benefits of internationalization, to the choice of investment location, to the selection of entry mode and nature of the foreign operations they seek to establish abroad.

\section{SOMNCs: Extending Theories of the Firm}

In addition to providing a cross-fertilization of the literatures on SOEs and MNCs, we argue that the analysis of SOMNCs can also extend specific theories of the firm. The key difference between SOMNCs and other MNCs is that they are owned by the government. Such ownership modifies some of the assumptions upon which the theories are built or their usual arguments, which have been developed from the analysis of private companies. We review some of the key theories of the firm and explain how their traditional arguments can be extended through the study of SOMNCs. ${ }^{5}$ Table 4 summarizes these ideas.

\section{Agency theory: The triple agency conflict argument}

Agency theory focuses on the management of relationships between two parties in which the agent is tasked by the principal to perform an action in the principal's name. ${ }^{6}$ The principal provides incentives and establishes control mechanisms on the agent so that the agent complies with the desires of the principal and not the agent's own (Holmstrom, 1979; Jensen \& Meckling, 1976).

Agency explanations of SOE behavior note the challenges that these firms face from the existence of a dual agency relationship. This dual agency differs from the traditional single agency relationships that exist in private, in which shareholders, as principals, may fail to control managers, who act as agents with objectives that diverge from the objectives of shareholders (Fama and Jensen, 1983). In the case of SOEs, there are additional complexities because of the existence of two agency relationships. First, the company is nominally owned by the citizens of the country who, as principals, task politicians, as agents, to achieve the social and economic objectives for which the SOE has been created. However, citizens do not have contractual mechanisms such as incentive systems or statutory limitations that enable them to align the objectives of politicians with their own objectives. In the case of SOEs, politicians are not controlled contractually by citizens. At most, citizens can replace politicians who fail to achieve their objectives after an election, and this happens only in democratic systems and for elected politicians. Second, politicians, as principals, task the managers of the SOE, who act as agents appointed by the politicians, to achieve their own objectives. The objectives of politicians are likely to differ from those of citizens, with politicians wanting to remain in power and citizens seeking better performance from SOEs. Both citizen and politician objectives are likely to differ from the SOE managers' objectives, who, rather than helping politicians obtain their own goals, are likely to be guided by their own career progression and preferences (Aharoni \& Lachman, 1982). The result is that SOEs suffer from a dual agency problem. Citizens do not have good control mechanisms over the misbehavior of firm managers and often have little control over the misbehavior of the politicians with SOE authority (Aharoni, 1982).

In the case of SOMNCs, there is a third agency relationship that further complicates the interactions among principals and agents: one between the managers of the SOMNC, as principals, and the managers of the foreign subsidiary of the SOE, as agents (Roth \& O'Donnell, 1996). This results in a set of three objectives that are likely to be in conflict: the managers at headquarters interested in advancing their own careers; the politicians interested in remaining in power; and the citizens interested in achieving the development of the home country. SOMNC subsidiary managers will have to integrate these three sets of objectives with their own desires for career advancement and independent decision making. Agency models need to be extended to account for the interactions among the objectives of these agents and principals, especially given that the objectives of the principals are not just simple performance measures, but can include development goals in the home country that can help politicians increase their political support. Additionally, in some SOMCs managers may enjoy autonomy and politicians may face 
Table 4 SOMNCs: Extending theories of the firm

\begin{tabular}{|c|c|c|c|c|c|}
\hline Theory & Agency & $\begin{array}{l}\text { Transaction cost } \\
\text { economics }\end{array}$ & Resource-based view & Resource dependence & Neo-institutional \\
\hline Initial arguments & $\begin{array}{l}\text { Jensen and Meckling (1976), } \\
\text { Holmstrom (1979) }\end{array}$ & $\begin{array}{l}\text { Coase }(1937), \text { Williamson } \\
(1975,1985)\end{array}$ & Penrose (1959), Barney (1991) & $\begin{array}{l}\text { Pfeffer and Salancik } \\
\text { (1978) }\end{array}$ & DiMaggio and Powell (1991) \\
\hline Assumption on & Bounded rationality & Bounded rationality & Bounded rationality & Bounded rationality & Bounded rationality \\
\hline individuals' & Imperfect information & Imperfect information & Imperfect information & Imperfect information & Imperfect information \\
\hline \multirow[t]{3}{*}{ behavior } & Information asymmetry & Information asymmetry & Information asymmetry & Information & Information asymmetry \\
\hline & Asset specificity & Asset specificity & Asset specificity & asymmetry & Asset specificity \\
\hline & Opportunism & Opportunism & & & \\
\hline Disciplinary basis & Economics & Economics & Economics & Sociology & Sociology \\
\hline $\begin{array}{l}\text { Key question on } \\
\text { ownership }\end{array}$ & $\begin{array}{l}\text { How can owners control the } \\
\text { misbehavior of managers? }\end{array}$ & $\begin{array}{l}\text { How can owners and } \\
\text { managers reduce } \\
\text { transaction costs in their } \\
\text { relationship? }\end{array}$ & $\begin{array}{l}\text { How can the firm benefit from } \\
\text { resources provided by owners } \\
\text { and managers? }\end{array}$ & $\begin{array}{l}\text { How can owners and } \\
\text { managers deal with } \\
\text { the power } \\
\text { relationship? }\end{array}$ & $\begin{array}{l}\text { How can owners facilitate the } \\
\text { legitimacy of the firm? }\end{array}$ \\
\hline $\begin{array}{l}\text { Key answer on } \\
\text { ownership }\end{array}$ & $\begin{array}{l}\text { Owners as principals need to } \\
\text { control managers as agents }\end{array}$ & $\begin{array}{l}\text { Owners cannot establish } \\
\text { full contractual } \\
\text { relationships with } \\
\text { managers }\end{array}$ & $\begin{array}{l}\text { Owners and managers select } \\
\text { unique sources of advantage to } \\
\text { the firm (which can be the } \\
\text { owners and managers) }\end{array}$ & $\begin{array}{l}\text { Managers depend on } \\
\text { owners for capital and } \\
\text { seek support }\end{array}$ & $\begin{array}{l}\text { Owners and managers implement } \\
\text { practices that are legitimate in the } \\
\text { environment }\end{array}$ \\
\hline $\begin{array}{l}\text { Key question on } \\
\text { internationalization }\end{array}$ & $\begin{array}{l}\text { How does an MNC ensure the } \\
\text { control of managers abroad? }\end{array}$ & $\begin{array}{l}\text { How does an MNC } \\
\text { internalize cross-border } \\
\text { transactions? }\end{array}$ & $\begin{array}{l}\text { How does an MNC expand and } \\
\text { compete across countries? }\end{array}$ & $\begin{array}{l}\text { How does an MNC } \\
\text { deal with power } \\
\text { relationships abroad? }\end{array}$ & $\begin{array}{l}\text { How does an MNC solve the } \\
\text { legitimation tensions between } \\
\text { home and host countries? }\end{array}$ \\
\hline $\begin{array}{l}\text { Key answer on } \\
\text { internationalization }\end{array}$ & $\begin{array}{l}\text { Managers at headquarters design } \\
\text { incentive and control systems to } \\
\text { align the behavior of subsidiary } \\
\text { managers with their objectives }\end{array}$ & $\begin{array}{l}\text { MNC uses a hierarchy in a } \\
\text { cross-border transaction } \\
\text { when the costs of using } \\
\text { contracts exceed the costs } \\
\text { of internalizing the } \\
\text { transaction }\end{array}$ & $\begin{array}{l}\text { Managers use and create firm- } \\
\text { specific assets that can be } \\
\text { transferred and provide the firm } \\
\text { an advantage abroad }\end{array}$ & $\begin{array}{l}\text { Managers coopt } \\
\text { powerful actors } \\
\text { abroad into the } \\
\text { company to reduce } \\
\text { their influence }\end{array}$ & $\begin{array}{l}\text { Managers organize decision } \\
\text { making and adopt practices that } \\
\text { provide legitimacy in the home } \\
\text { and host countries }\end{array}$ \\
\hline $\begin{array}{l}\text { Potential } \\
\text { theoretical } \\
\text { extension from the } \\
\text { analysis of SOE } \\
\text { MNCs }\end{array}$ & $\begin{array}{l}\text { The triple agency conflict argument: } \\
\text { Subsidiary managers make } \\
\text { decisions to accomplish } \\
\text { conflicting objectives of three } \\
\text { principals: citizens, politicians and } \\
\text { headquarter managers }\end{array}$ & $\begin{array}{l}\text { The owner risk argument: } \\
\text { The government as owner } \\
\text { can tolerate higher risk in } \\
\text { cross-border transactions }\end{array}$ & $\begin{array}{l}\text { The advantage and disadvantage } \\
\text { of ownership argument: Managers } \\
\text { use the government as a source } \\
\text { of advantage abroad but the } \\
\text { government can also become a } \\
\text { source of disadvantage abroad }\end{array}$ & $\begin{array}{l}\text { The power escape } \\
\text { argument: Managers } \\
\text { internationalize the } \\
\text { firm to reduce the } \\
\text { influence of the home } \\
\text { government }\end{array}$ & $\begin{array}{l}\text { The illegitimate ownership } \\
\text { argument: Company is perceived } \\
\text { as less legitimate abroad because } \\
\text { of state ownership and } \\
\text { ideological/political strategy } \\
\text { conflicts about state ownership }\end{array}$ \\
\hline
\end{tabular}


constraints on interfering with their business decisions, further complicating the agency analysis of SOEs as these managers enjoy the autonomy that few managers of private firms may have.

The triple agency problem of SOMNCs is likely to result in SOMNCs investing in foreign projects that have lower business value than those selected by private MNCs. There are several reasons for this. First, citizens may task the SOEs with a mandate to achieve social and economic objectives in the home country that increase the welfare of citizens at home. This mandate may not require the firm to invest abroad. However, politicians may task managers with a mandate to achieve political objectives abroad. These competing demands are not faced by private MNCs. SOMNC managers may not be able to reconcile these competing demands between citizens and politicians when investing abroad, because what is perceived as a strategic action by citizens and by politicians is likely to differ. Citizens and politicians may also differ in their definition of what constitutes a strategic industry. Citizens are likely to focus on their current welfare and consumption and deem utilities and infrastructure of high value, whereas politicians may focus on exercising influence over other countries or ensuring the long-term supply of inputs such as natural resources and energy. Thus, managers of SOMNCs may internationalize and select countries based on which group exercises the most influence. The result could be subsidiaries with erratic behavior as SOMNC managers try to meet the objectives of both citizens and politicians.

Second, politicians may select and task managers to achieve objectives that are beneficial to the politicians themselves but detrimental to the SOE and its home country citizens. For example, the SOE may be required to provide subsidized energy or infrastructure to other countries to maintain influence over those countries. Such behavior may lead to foreign investments that are unprofitable or too expensive and are done because the investment is perceived as a way to enhance the international status of the politicians. The Venezuelan government has required the state national oil company PDVSA to sell deeply subsidized oil to Cuba, Jamaica, Haiti and Nicaragua, which was detrimental to PDVSA's profitability and to Venezuelan citizens who effectively paid for the subsidy.

Third, managers of SOEs who are poorly monitored and controlled may embark on "empire building" and may purse an internationalization strategy that gives them prestige, but may economically hurt their firms (Cui \& Jiang, 2012; Vernon, 1979). For instance, SOEs that internationalize because of the prestige objectives of their managers may overpay for foreign assets or may buy unprofitable target firms. This is more likely to happen in SOEs that are fully owned by the government and not publicly traded, since managers may not face any punishment for making such poor investments. In SOEs that are publicly traded, investors may penalize the behavior of managers with lower valuations (Knutsen et al., 2011). The lower valuations may not be enough to realign SOMNC managerial objectives because the managers are not likely to be subject to the same market disciplines as private MNC managers.

We summarize these ideas in the following proposition:

Proposition 1: SOMNCs are more likely to enter countries and invest in projects that have lower business value than those undertaken by private MNCs.

Transaction cost economics: The owner risk argument Transaction cost economics explains firm behavior based on the cost of transactions in economic relationships among actors. Transaction costs emerge from the existence of information asymmetries and imperfect contracting coupled with asset specificity and opportunism (Williamson, 1985). These costs can be identified based on the specificity of the assets involved and the possibility of writing contracts and establishing controls under imperfect and asymmetric information. Transaction costs tend to be independent of the actors involved; at most they are associated with the propensity toward opportunistic behavior by economic actors.

In the case of SOMNCs, the perceptions of transaction costs differ from those that can be gleaned from asset specificity, imperfect contracting and asymmetric information. The reason is not because the government is less likely to act opportunistically than private owners, but because the government has a different risk tolerance than private owners. Governments have larger budgets and resources that enable them to take more risks, and they can be more patient investors (Kaldor, 1980). Additionally, they have control over laws and regulations that enable them to enforce contracts and reduce risks.

Therefore, compared to private firms, SOMNCs are more likely and willing to make risky investments in the country environments in which they invest (i.e., countries with weaker rule of law or higher expropriation risk), in the industries or fields in which they invest and in the risk-profile of the investments. This behavior is explained by two features of 
SOMNCs. First, SOMNCs face a soft-budget constraint (i.e., their home governments can bail them out if they run into financial difficulties), an institutional feature that may lead these firms and their managers to take on more risk than their private counterparts (Kornai, 1979; Vernon, 1979). Thus, when assessing foreign investments, the SOMNC hurdle rate is in effect lower than those of private MNCs, as SOMNCs can have access to government support or low-cost government capital. This lower hurdle enables them to take projects that are riskier and have a higher probability of default. For example, it is well known in the oil industry that Chinese national oil companies are often willing to accept lower returns than privately held international oil companies.

Second, SOMNCs face lower expropriation risk because they have the implicit backing of their home country governments, especially when those governments are powerful (Knutsen et al., 2011). The government can use political relationships and diplomacy and the creation of bilateral investment treaties that favor SOMNCs to reduce the potential expropriation of SOMNCs abroad. This is particularly the case for governments of large countries, which are in a better position to exercise influence over governments of smaller countries by threatening to limit the latter's access to its market or by taking those host governments to the World Trade Organization or the International Centre for Settlement of Investment Disputes to address the investment and trade disputes of their SOMNCs. A similar dynamic can take place in the case of home countries that are important suppliers of raw materials and energy to the host government, as the home government can threaten to reduce supply if its SOMNCs are harmed by the host government. Thus, managers of SOMNCs can enter countries that are deemed too risky for private investors and face lower probability of expropriation than private MNCs because of the protection they enjoy from their home government.

These arguments can be summarized in the following proposition:

Proposition 2: SOMNCs are more likely to enter countries and invest in projects that are riskier than those undertaken by private MNCs.

\section{RBV: The advantage and disadvantage of ownership argument}

The RBV focuses on how firms can develop and use resources and capabilities to serve customers and achieve an advantage over competitors (Penrose,
1959). Companies become multinationals when they have resources that can be transferred abroad and that provide them with an advantage over host country competitors in satisfying the need of customers in the host country (Tallman \& Yip, 2001).

Extending the RBV to the analysis of SOMNCs, we argue that the state ownership of SOMNCs can be viewed as a resource with a dual influence on the SOMNC's competitive advantage abroad. ${ }^{7}$ On the one hand, government ownership or backing can be a source of an advantage when it provides SOMNCs with subsidized credit or diplomatic support to deal with foreign governments. The government can provide the SOMNC with ample funds for investment that may not be available to private firms, enabling it to make larger investments. Moreover, the government can use its diplomatic relationships with the host country government to facilitate the expansion of the SOMNC. For example, it can provide subsidized credit to the host country to build infrastructure that will be used by the home country's SOMNCs. It can also negotiate conditions in its bilateral investment treaties that are designed to favor the business of its SOMNCs in the host country, designating specific industries that are favored for its SOMNCs.

We summarize these ideas in the following proposition:

Proposition 3a: SOMNCs are more likely to invest in larger projects abroad than are private MNCs.

On the other hand, government ownership can be a source of disadvantage in the firm's internationalization because host country governments or consumers abroad discriminate against foreign governments (Cui \& Jiang, 2012). This is different from the broader disadvantage of foreignness, in which foreign firms or firms from particular foreign countries are discriminated against because the government or consumers have nationalistic attitudes (Cuervo-Cazurra, Maloney, $\&$ Manrakhan, 2007). The disadvantage of ownership is about SOMNCs being discriminated against because they are SOEs, not because they are MNCs. This negative dimension of ownership is rarely discussed, as owners tend to be viewed positively as providers of financial resources and in some cases as providers of advice. In fact, SOMNCs can be perceived as a threat to the hosts' national security because of their links to their home government (Globerman \& Shapiro, 2009). Thus, we expect that SOMNCs, in comparison to private MNCs, are more commonly blocked when they bid for assets that are considered strategic by host governments (e.g., natural resources, 
infrastructure, utilities). Additionally, when state ownership of SOMNCs creates hostility, SOMNCs will tend to increase investment spillovers to compensate for the disadvantage created by their state ownership. SOMNCs will prefer greenfield operations over acquisitions to avoid the controversy associated with a foreign government-owned company buying a domestic company. A wholly owned greenfield investment redirects attention toward a foreign government investing in the creation of new productive facilities in the host country that can generate additional employment and development rather than to the transfer of existing facilities to a foreign government.

We summarize these arguments in the following proposition:

Proposition 3b: SOMNCs are more likely to face hostility in their foreign investments and are more likely to prefer greenfield investments over acquisitions than are private MNCs.

\section{Resource dependence theory: The power escape argument}

Resource dependence theory analyzes power relationships among two parties. One party is able to exercise power over the other when the latter depends on the former for some resource. The traditional solution to reducing power relationships is to co-opt those that have power and integrate them within the company, linking their objectives to those of the firm (Pfeffer \& Salancik, 1978). Hence, in firms that depend on the government for support, for example, to obtain loans from state-owned banks or to get beneficial regulation, managers can co-opt the government by including politicians among its board members, perhaps even with pay for performance schemes, to ensure that their desires are aligned with those of the firm. However, in the case of SOEs, politicians are already members of the board of directors and managers are likely to have been appointed by the politicians. Thus, politicians may still try to steer the firm to pursue political objectives of little value to the firm but of high value to the politician.

Thus, an alternative way to reduce the influence of such politicians would be to depend less on government funds and support (Noreng, 1994), and this could be done by internationalizing the firm. ${ }^{8}$ SOMNC managers, rather than trying to co-opt politicians and government officials into the company, can use the international expansion of the firm to escape from the control of politicians. By investing in other countries and obtaining a steady source of revenues from abroad, the SOMNC can reduce its dependence on the politicians at home and thus the power that the government exercises over it. When home country governments are facing tight budget constraints or are reigning in the expenditures of SOEs, the managers of SOMNCs will seek international expansion to obtain new sources of cash flow, either by investing in subsidiaries abroad or by increasing their exports. For example, Trebat (1985) argues that Brazilian SOEs in the 1970s embarked on a process of diversification and internationalization in order to maintain financial autonomy from the government. This may be more apparent in firms in which managers enjoy a degree of autonomy from political influence (Aharoni, 1982) and thus managers are freer to deepen their autonomy by taking the firm abroad.

We summarize these arguments in the following proposition:

Proposition 4: SOMNCs are more likely to internationalize to reduce the power of government influence than private firms.

\section{Neo-institutional theory: The illegitimate owner argument}

Neo-institutional theory focuses on understanding the achievement of legitimacy needed to operate in a foreign country. Companies respond to the cognitive, normative and regulatory pressures of the environment and imitate practices that are perceived as legitimate (DiMaggio \& Powell, 1991). As the firm becomes an MNC, it faces two sets of pressures on its legitimacy, from the home country headquarters and from the host country environment, which can be in conflict (Kostova \& Zaheer, 1999).

SOMNCs face an additional pressure on their legitimacy abroad since government ownership can become a source of illegitimacy in the host country. The host country government and citizens may view the SOMNC as an instrument of another government aiming to exercise control in the host country economy. This perception of SOE illegitimacy will depend on conditions such as the level of state ownership or the ideology or political strategy of the ruling government in the host country. Thus, SOMNCs may choose countries in which they are perceived as more legitimate, either because there are more similarities between the home and host governments in their political ideology and strategies or because the local economy is already dominated by host country SOEs and thus state ownership of firms is not perceived as illegitimate. 
We summarize these ideas in the following proposition:

Proposition 5a: SOMNCs are more likely to select host countries in which their state ownership is perceived as more legitimate than host countries in which there is less legitimacy of state ownership.

Nevertheless, SOMNCs may need to invest in countries in which their state ownership is not perceived as legitimate because the host country is the appropriate location for investment. In such countries, the SOMNC may have to engage in more legitimacy building than private firms to facilitate its operation in the host country. SOMNCs that are publicly traded at home or in other financial centers and that follow corporate governance practices that mimic those of private firms may be perceived as less threatening by their host governments. Alternatively, SOMNCs may establish alliances with local firms that provide them with local legitimacy and similarity to local firms. For example, many of the SOMNCs in the energy sector have mitigated the likely negative impact of host government hostility by entering into mutually beneficial alliances with both private and governmentowned host country entities. Additionally, SOMNCs may make greater investments in corporate social responsibility to ensure the support of citizens and local politicians and increase their legitimacy.

We summarize these ideas in the following proposition:

Proposition 5b: SOMNCs are more likely to engage in legitimacy building actions in host countries than private MNCs.

\section{Extension of Theories by the Articles in this Special Issue}

These proposed extensions of theory by analyzing SOMNCs are accomplished in more detail and depth in the articles included in this special issue. State ownership opens many questions and potential research avenues, and the articles included in this special issue span theoretical boundaries to create new frameworks and ideas, extend existing theories and enhance our understanding of the complexities associated with state-directed global investments. Although some areas of inquiry, such as the wellestablished work on privatization, transitional economies and emerging market multinationals, are all critical areas of work, this special issue exclusively focuses on the internationalization of SOEs and their impact on the global strategy landscape.
The initial call for papers on "Government as Owners: Globalizing State-Owned Enterprises" was issued in October 2012, and we received 55 papers. After two rounds of reviews, the remaining 7 papers were invited for a conference at Harvard Business School on 21 September 2013, which was generously supported by Harvard Business School, Northeastern University and its Center for Emerging Markets, and Thunderbird School of Global Management. At the conference, the authors presented the main ideas of the papers and the audience provided suggestions for improvement, which were incorporated in another round of revisions. The final seven articles provide unique contributions to the literature by using the internationalization of SOEs to extend theories. Table 5 summarizes the papers. We present them in order of the theory they extend, starting with the sociology-based theories of resource dependence and institutional theory, followed by the economics-based theories of transaction costs economics, stewardship and agency theory.

Choudhury and Khanna (2014) wrote the paper titled "Toward resource independence - Why stateowned entities become multinationals: An empirical study of India's public R\&D laboratories." In it they extend the resource dependence theory by proposing internationalization as an escape from the control of the government over managers. Their analysis of Indian state-owned laboratories finds that these entities aggressively filed foreign patents and licensed these foreign patents to multinationals to create a cash flow stream independent of government budgetary support, helping them achieve partial resource independence from other state actors.

Bass and Chakrabarty (2014), in their paper titled "Resource security: Competition for global resources, strategic intent, and governments as owners," examine the cross-border acquisition of resources by SOMNCs in comparison to private MNCs. They build on resource dependence theory and analyze the global oil industry to argue that private MNCs prefer short-term secure resources for immediate benefits, whereas SOMNCs seem to be willing to invest in long-term secure resources as a safeguard for the future. They reason that the owners of SOMNCs governments - are concerned with securing access to energy resources, the lack of which could threaten the economy of the home country. These arguments highlight how state- and private-owned multinationals view resource security differently.

$\mathrm{Li}$, Cui and $\mathrm{Lu}$ (2014), in their theoretical paper "Varieties in state capitalism: Outward FDI strategies of central and local state-owned enterprises from 
Table 5 Summary of the Papers Included in the Special Issue

\begin{tabular}{|c|c|c|c|c|}
\hline Article & $\begin{array}{l}\text { Research } \\
\text { question }\end{array}$ & Theory & Argument & Empirical setting \\
\hline $\begin{array}{l}\text { Choudhury and Khanna (2014). Toward resource } \\
\text { independence - why state-owned entities become } \\
\text { multinationals: an empirical study of India's public R\&D } \\
\text { laboratories }\end{array}$ & $\begin{array}{l}\text { Why do SOEs } \\
\text { internationalize? }\end{array}$ & $\begin{array}{l}\text { Resource } \\
\text { dependence }\end{array}$ & $\begin{array}{l}\text { SOEs internationalize to reduce control by the } \\
\text { government }\end{array}$ & $\begin{array}{l}42 \text { national Indian } \\
\text { state-owned } \\
\text { laboratories, } \\
1993-2006\end{array}$ \\
\hline $\begin{array}{l}\text { Bass and Chakrabarty (2014). Resource security: } \\
\text { competition for global resources, strategic intent and } \\
\text { governments as owners }\end{array}$ & $\begin{array}{l}\text { How do SOEs } \\
\text { internationalize? }\end{array}$ & $\begin{array}{l}\text { Resource } \\
\text { dependence }\end{array}$ & $\begin{array}{l}\text { SOEs are more likely and pay more for exploration than } \\
\text { exploitation resources abroad }\end{array}$ & $\begin{array}{l}404 \text { cross-border } \\
\text { transactions in the } \\
\text { global oil industry, } \\
2005-2012\end{array}$ \\
\hline $\begin{array}{l}\text { Li, Cui and Lu (2014). Varieties in state capitalism: outward } \\
\text { FDI strategies of central and local SOEs from emerging } \\
\text { economy countries }\end{array}$ & $\begin{array}{l}\text { How do SOEs } \\
\text { internationalize? }\end{array}$ & $\begin{array}{l}\text { Neo } \\
\text { institutional }\end{array}$ & $\begin{array}{l}\text { Institutional change in the home country leads centrally } \\
\text { and locally owned SOEs to internationalize differently }\end{array}$ & Theory \\
\hline $\begin{array}{l}\text { Meyer, Ding, Li and Zhang (2014). Overcoming distrust in } \\
\text { host societies: How SOEs adapt their foreign entries to } \\
\text { institutional pressures }\end{array}$ & $\begin{array}{l}\text { How do SOEs } \\
\text { enter foreign } \\
\text { countries? }\end{array}$ & $\begin{array}{l}\text { Neo } \\
\text { institutional }\end{array}$ & $\begin{array}{l}\text { SOE are subject to different legitimation pressures than } \\
\text { private firms that lead them to use more acquisitions but } \\
\text { with less control }\end{array}$ & $\begin{array}{l}298 \text { foreign subsidiaries } \\
\text { of publicly traded } \\
\text { Chinese firms, } 2009\end{array}$ \\
\hline $\begin{array}{l}\text { Pan, Teng, Supapol, Lu, Huang and Wang (2014). Firm's } \\
\text { FDI ownership: the influence of government ownership and } \\
\text { legislative connections }\end{array}$ & $\begin{array}{l}\text { How do SOEs } \\
\text { enter foreign } \\
\text { countries? }\end{array}$ & $\begin{array}{l}\text { Transaction } \\
\text { cost }\end{array}$ & $\begin{array}{l}\text { State ownership and political connections moderate the } \\
\text { relationship between the foreign institutional } \\
\text { environment and the level of ownership of foreign } \\
\text { subsidiaries }\end{array}$ & $\begin{array}{l}1617 \text { foreign } \\
\text { subsidiaries of } 594 \\
\text { Chinese publicly traded } \\
\text { firms, } 2010\end{array}$ \\
\hline $\begin{array}{l}\text { Liang, Ren, and Sun (2014). An anatomy of state control in } \\
\text { SOEs' globalization }\end{array}$ & $\begin{array}{l}\text { How much do } \\
\text { SOEs } \\
\text { internationalize? }\end{array}$ & Agency & $\begin{array}{l}\text { Changes in the institutional environment modify how } \\
\text { state ownership and political connections lead SOEs to } \\
\text { different levels of internationalization }\end{array}$ & $\begin{array}{l}2394 \text { publicly traded } \\
\text { Chinese firms, 2001- } \\
2011\end{array}$ \\
\hline $\begin{array}{l}\text { Duanmu (2014). State-owned MNCs and host country } \\
\text { expropriation risk: the role of home state power and } \\
\text { economic gunboat diplomacy }\end{array}$ & $\begin{array}{l}\text { Where do SOEs } \\
\text { invest abroad? }\end{array}$ & Agency & $\begin{array}{l}\text { SOEs are more likely to invest in risky countries and in } \\
\text { countries with strong connections to the home country }\end{array}$ & $\begin{array}{l}894 \text { greenfield foreign } \\
\text { investments by Chinese } \\
\text { firms, 2003-2010 }\end{array}$ \\
\hline
\end{tabular}


emerging economy countries," discuss heterogeneity in internationalization among SOEs and explain that this heterogeneity as the result of institutional reform processes in emerging economies. They develop a trickle-down theoretical framework linking comparative capitalisms and diversity in capitalism theories to sociological institutionalism by advancing the idea of "institutions-as-configurations" to explain how macro-institutional reforms in the home country can engender institutional diversity and evolution of different types of SOEs with distinct behaviors and agendas. They explain how macro patterns of institutional change result in micro-level heterogeneity among SOEs and highlight the implications of such diversity for their FDI strategies, explaining the differences in internationalization by centrally and locally owned SOMNCs.

Meyer, Ding, Li and Zhang (2014), in the paper titled "Overcoming distrust: How state-owned enterprises adapt their foreign entries to institutional pressures abroad," extend the neo-institutional theory to discuss the entry mode of SOMNCs in comparison to private MNCs. SOEs are subject to more complex institutional pressures not only at home but also in foreign investment locations. Government ownership reduces legitimacy abroad and induces SOMNCs to use fewer acquisitions and to have lower levels of control of foreign investments. They test these arguments on a sample of foreign subsidiaries of Chinese firms.

Pan, Teng, Supapol, Lu, Huang and Wang (2014), in their article titled "Firms' FDI ownership: The influence of government ownership and legislative connections," incorporate firms' political connectedness into the analysis of transaction costs. They argue that government ownership and legislative connections moderate the prediction of transaction costs on the relationship between the heterogeneity of foreign institutional environments and firms' foreign subsidiary ownership, testing these arguments on a sample of Chinese publicly traded firms. The study adds to a better understanding of the role of political connectedness in firms' FDI activities.

Liang, Ren, and Sun (2014) wrote the article "An anatomy of state control in the globalization of state-owned enterprises," which appears in a subsequent issue of the journal because of space constraints, in which they identify two types of state control in the globalization of SOEs from emerging economies: state ownership control as a regulative force and executives' political connections as a normative force. They argue that changes in the institutional environment of the home country alter the impact of these two types of state control on the level of internationalization of SOEs, analyzing these relationships in a sample of Chinese publicly traded firms. By extending the agency perspective and integrating it with the institutional analysis in political economy and IB, their state control perspective offers a fundamental understanding of the rise of SOEs from emerging economies in the global arena.

Duanmu (2014), in the paper titled "State-owned MNCs and host country expropriation risk: The role of home state power and economic gunboat diplomacy," analyzes the risk of expropriation abroad. Building on agency theory, she proposes that SOMNCs can use the political support of their home governments to counter the monopoly power of the host states and thus reduce expropriation risks. Using a sample of Chinese foreign investments, she finds that foreign investment by SOMNCs is less deterred by expropriation risk in the host country, especially in countries that have strong political relations with and high export dependence on China.

\section{CONCLUSION}

SOMNCs continue to evolve as governments privatize companies but keep majority and minority stakes, while new forms of state ownership in the form of SWFs, state-owned pension funds and state-owned banks have emerged. This introduction to the special issue highlights the importance of SOMNCs as a topic for analysis to provide a better understanding not only of these firms, but also of theories of the firm. The analysis of SOMNCs helps extend traditional arguments of both SOEs and MNCs, leading us to introduce the extraterritoriality and the non-business internationalization arguments. We complemented these topical extensions with the extensions of five theories, introducing additional arguments: the triple agency conflict argument in agency theory, the owner risk argument in transaction cost economics, the advantage and disadvantage of ownership argument in RBV, the power escape argument in resource dependence and the illegitimate ownership argument in neo-institutionalism. The papers included in the special issue provide depth to these and other extensions of theories and illustrate how the study of SOMNCs can be used to extend both our understanding of these firms and our understanding of theories.

With these ideas we provide an integrative platform to help IB scholars address the core issues that dominate debates on the global role of SOEs that are reshaping the impact of the state in global economic activity. 


\section{ACKNOWLEDGEMENTS}

The authors would like to thank John Cantwell and three anonymous reviewers for useful suggestions for improvement. Cuervo-Cazurra thanks the Walsh Professorship, the Robert Morrison Fellowship and the Center for Emerging Markets at Northeastern University for financial support. Inkpen thanks the Seward Chair in Global Strategy for financial support. Musacchio thanks the funding from the Division of Research and Faculty Development at Harvard Business School. Ramaswamy thanks the William D. Hacker Chair in Management for financial support. All errors are of the authors.

\section{NOTES}

${ }^{1} \mathrm{~A}$ different discussion is the analysis of the relationship between managers and policymakers, which has been analyzed under the term "non-market strategies" (Barron, 1995). This differs markedly from the ideologies or political strategies of politicians that lead them to create SOEs. Non-market strategies are actions taken after the firm is created, and can be taken by managers of SOEs as well as managers of private firms.

${ }^{2}$ This approach differs from the varieties of capitalism literature (e.g., Hall \& Soskice, 1991) that classified advanced economies into liberal market economies and coordinated market economies, because we focus on the ideology regarding ownership of factors of production rather than the broader ideology of the coordination of labor and capital relationships. For a discussion of the international dimension of this view see Whitley (1998).

${ }^{3}$ In this discussion we focus on the economic dimension of these ideologies and political strategies. The political implications of communism or social democracy, such as the promotion of totalitarian or democratic regimes, are outside the scope of analysis of this paper.

\section{REFERENCES}

Aharoni, Y. 1982. State-owned enterprise: An agent without a principal. In L. Jones (Ed), Public enterprise in less-developed countries, 67-76. New York: Cambridge University Press.

Aharoni, Y. 1986. The evolution and management of state owned enterprises. Cambridge, MA: Ballinger Publishing.

Aharoni, Y., \& Lachman, R. 1982. Can the manager's mind be nationalized? Organization Studies, 3(1): 33-46.

Anastassopoulos, J. P., Blanc, G., \& Dussauge, P. 1987. State-owned multinationals. New York: Wiley.

Anderson, E., \& Gatignon, H. 1986. Modes of foreign entry: A transaction cost analysis and propositions. Journal of International Business Studies, 17(1): 1-26.

Arocena, P., \& Oliveros, D. 2012. The efficiency of state-owned and privatized firms: Does ownership make a difference? International Journal of Production Economics, 140(1): 457-465.
${ }^{4}$ Following Aharoni (1986) we refer to SOEs as productive firms, which are firms that produce "goods and services for sale. This function distinguishes SOEs from other public sector activities that are more in the nature of public goods (such as defense, police or courts)" (6). In our view the later organizations should be differentiated from SOEs, thus we include them in Table 1 as government agencies.

${ }^{5}$ Although many SOMNCs come from emerging markets, not all do. In this article we focus on analyzing how the analysis of SOMNCs can help advance selected theories. Reviews of how the analysis of emerging market MNCs can help advance theories appear in Cuervo-Cazurra (2012) and in Ramamurti (2012).

${ }^{6} \mathrm{~A}$ competing view of relationships is stakeholder theory (Freeman, 2010), which focuses on analyzing how the different stakeholders of the firm exert competing demand and influence firm behavior. A review of this theory is outside this paper's scope of analysis.

${ }^{7}$ This differs from the analysis of how the country of origin affects the internationalization of the firm (for a short review see Cuervo-Cazurra, 2011), as we focus on how state ownership rather than the particular country of origin affects international expansion.

${ }^{8} \mathrm{~A}$ related idea is the institutional escape argument (Van Tulder \& van der Zwart, 2006), in which companies invest abroad to escape the weak institutions of the home country (Witt \& Lewin, 2007). This institutional escape argument operates at the country level, with country-level conditions inducing the firm to internationalize, and applies both to private firms as well as to SOEs which seek countries with stronger institutions. Our power escape argument operates at the firm level, with firm-level characteristics inducing managers to internationalize the firm, and in particular applies to managers of SOEs aiming to reduce the influence of the role of politicians as representatives of the owners, and can take place in countries with weak as well as with strong institutions.

Barney, J. B. 1991. Firm resources and sustained competitive advantage. Journal of Management, 17(1): 99-120.

Baron, D. P. 1995. Integrated strategy: Market and nonmarket components. California Management Review, 37(2): 47-65.

Bass, E., \& Chakrabarty, S. 2014. Resource security: Competition for global resources, strategic intent, and governments as owners. Journal of International Business Studies, 45(8): 961-979.

Bruton, H. J. 1998. A reconsideration of import substitution. Journal of Economic Literature, 36(2): 903-936.

Buckley, P. J., \& Casson, M. 1976. The future of the multinational enterprise. New York: Holmes \& Meier.

Buckley, P. J., Clegg, J., Cross, A., Liu, X., Voss, H., \& Zheng, P. 2007. The determinants of Chinese outward foreign direct investment. Journal of International Business Studies, 38(4): 499-518. 
Cardoso, F. H., \& Faletto, E. 1979. Dependency and development in Latin America. University of California Press.

Cheng, J. L. C., Henisz, W. J., Roth, K., \& Swaminathan, A. 2009. Advancing interdisciplinary research in the field of international business: Prospects, issues and challenges. Journal of International Business Studies, 40(7): 1070-1074.

Choudhury, P., \& Khanna, T. 2014. Toward resource independence - Why state-owned entities become multinationals: An empirical study of India's public R\&D laboratories. Journal of International Business Studies, 45(8): 943-960.

Coase, R. H. 1937. The nature of the firm. Economica, 4(16): 386-405

Cuervo-Cazurra, A. 2011. Global strategy and global business environment: The direct and indirect influences of the home country on a firm's global strategy. Global Strategy Journal, 1(3-4): 382-386.

Cuervo-Cazurra, A. 2012. Extending theory by analyzing developing country multinational companies: Solving the Goldilocks debate. Global Strategy Journal, 2(3): 153-167.

Cuervo-Cazurra, A., Maloney, M., \& Manrakhan, S. 2007. Causes of the difficulties in internationalization. Journal of International Business Studies, 38(5): 709-725.

Cui, L., \& Jiang, F. 2012. State ownership effect on firms' FDI ownership decisions under institutional pressure: A study of Chinese outward-investing firms. Journal of International Business Studies, 43(3): 264-284.

Datta, D. K., Herrmann, P., \& Rasheed, A. A. 2002. Choice of foreign market entry modes: Critical review and future directions. Advances in International Comparative Management, 14: 85-154.

Desai, M. A., Foley, C. F., \& Hines, Jr., J. R. 2005. Foreign direct investment and the domestic capital stock. American Economic Review, 95(1): 33-38.

DiMaggio, P. J., \& Powell, W. 1991. The new institutionalism in organizational analysis. Chicago: University of Chicago Press.

Duanmu, J. L. 2014. State-owned MNCs and host country expropriation risk: The role of home state soft power and economic gunboat diplomacy. Journal of International Business Studies, 45(8): 1044-1060.

Dunning, J. H. 1993. Multinational enterprises and the global economy. Wokingham, UK: Addison Wesley.

Dutton, 1. 1982. The optimal taxation of international investment income: A comment. The Quarterly Journal of Economics, 97(2): 373-380.

The Economist. 2012. Emerging-market multinationals: The rise of state capitalism. 21 January, www.economist.com/node/ 21543160, accessed 17 October 2013.

Fama, E. F., \& Jensen, M. C. 1983. Separation of ownership and control. Journal of Law and Economics, 26(2): 301-325.

Feldstein, M. 1994. The effects of outbound foreign direct investment on the domestic capital stock. NBER Working Paper No. 4668, NBER, Cambridge, MA.

Freeman, R. E. 2010. Strategic management: A stakeholder approach. Cambridge: Cambridge University Press.

Gerard, L. 2007. State capitalism: The rise of sovereign wealth funds. Journal of Management Research, 7(3): 119-146.

Globerman, S., \& Shapiro, D. 2009. Economic and strategic considerations surrounding Chinese FDI in the United States. Asia Pacific Journal of Management, 26(1): 163-183.

Gustafson, T. 2012. Putin's petroleum problem. Foreign Affairs, November-December, http://www.foreignaffairs.com/articles/ $138363 /$ thane-gustafson/putins-petroleum-problem, accessed 18 April 2014

Hall, P. A., \& Soskice, D. (Eds) 1991. Varieties of capitalism: The institutional foundations of comparative advantage. New York: Oxford University Press.

Holmstrom, B. 1979. Moral hazard and observability. Bell Journal of Economics, 10(1): 74-91.

Hymer, S. H. 1976. The international operations of national firms: A study of foreign direct investment. Cambridge, MA: MIT Press.
Inoue, C., Lazzarini, S. G., \& Musacchio, A. 2013. Leviathan as a minority shareholder: Firm-level implications of state equity purchases. Academy of Management Journal, 56(6): 1775-1801.

Jensen, M. C., \& Meckling, W. H. 1976. Theory of the firm: Managerial behavior, agency costs and ownership structure. Journal of Financial Economics, 3(4): 305-360.

Johanson, J., \& Vahlne, J. E. 1977. The internationalization process of the firm: A model of knowledge development and increasing foreign market commitments. Journal of International Business Studies, 8(1): 23-32.

Jones, L. P., \& Mason, E. S. 1982. Role of economic factors in determining the size and structure of the public-enterprise sector in less-developed countries with mixed economies. In L. Jones (Ed), Public enterprise in less-developed countries, 17-99. New York: Cambridge University Press.

Kaldor, N. 1980. Public or private enterprise - The issue to be considered. In W. J. Baumol (Ed), Public and private enterprises in a mixed economy, 1-12. New York: St. Martin's.

Kaul, I., Grunberg, I., \& Stern, M. (Eds) 1999. Global public goods: International cooperation in the 21 st century. Oxford: Oxford University Press.

Knutsen, C. H., Rygh, A., \& Hveem, H. 2011. Does state ownership matter? Institutions' effect on foreign direct investment revisited. Business and Politics, 13(1): 1-33.

Kornai, J. 1979. Resource-constrained versus demandconstrained systems. Econometrica, 47(4): 801-819.

Kostova, T., \& Zaheer, S. 1999. Organizational legitimacy under conditions of complexity: The case of the multinational enterprise. Academy of Management Review, 24(1): 64-81.

Laffont, J. J., \& Tirole, J. 1993. A theory of incentives in regulation and procurement. Cambridge, MA: MIT Press.

Lawson, C. 1994. The theory of state-owned enterprises in market economies. Journal of Economic Surveys, 8(3): 284-309.

Le Grand, J. 1991. The theory of government failure. British Journal of Political Science, 21(4): 423-442.

Levy, B. 1987. A theory of public enterprise behavior. Journal of Economic Behavior and Organization, 8(1): 75-96.

Li, M. H., Cui, L., \& Lu, J. 2014. Varieties in state capitalism: Outward FDI strategies of central and local state-owned enterprises from emerging economy countries. Journal of International Business Studies, 45(8): 980-1004.

Liang, H., Ren, B., \& Sun, S. L. 2014. An anatomy of state control in the globalization of state-owned enterprises. Journal of International Business Studies, advance online publication 17 July, doi:10.1057/jibs.2014.35.

Lindsay, C. M. 1976. A theory of government enterprise. Journal of Political Economy, 84(5): 1061-1077.

Marx, K. 1906. (1867). Capital: A critique of political economy, Vol. I. The process of capitalist production. Chicago: Charles $\mathrm{H}$ Kerr and Co.

Marx, K., \& Engels, F. 1893. (1848). Communist manifesto. Chicago: Charles H. Kerr \& Co.

Mazzolini, R. 1979. European government-controlled enterprises: Explaining international strategic and policy decisions. Journal of International Business Studies, 10(1): 16-27.

Megginson, W. L., \& Netter, J. M. 2001. From state to market: A survey of empirical studies on privatization. Journal of Economic Literature, 39(2): 321-389.

Meyer, K., Ding, Y., Li, J., \& Zhang, H. 2014. Overcoming distrust: How state-owned enterprises adapt their foreign entries to institutional pressures abroad. Journal of International Business Studies, 45(8): 1005-1028.

Musacchio, A., \& Lazzarini, S. G. 2014. Reinventing state capitalism: Leviathan in business, Brazil and beyond. Cambridge, MA: Harvard University Press.

Noreng, O. 1994. National oil companies and their government owners: The politics of interaction and control. Journal of Energy and Development, 19(2): 197-226.

Pan, Y., Teng, L., Supapol, A. B., Lu, X., Huang, D., \& Wang, Z. 2014. Firms' FDI ownership: The influence of government 
ownership and legislative connections. Journal of International Business Studies, 45(8): 1029-1043.

Penrose, E. T. 1959. The theory of the growth of the firm. Oxford: Oxford University Press.

Pfeffer, J., \& Salancik, G. 1978. The external control of organizations: A resource dependence approach. New York: Harper \& Row.

Prebisch, R. 1959. Commercial policy in the underdeveloped countries. American Economic Review, 49(2): 251.

Pryke, R. 1971. Public enterprise in practice: The British experience of nationalization over two decades. London: MacGibbon and Kee.

Ramamurti, R. 2012. What is really different about emerging market multinationals? Global Strategy Journal, 2(1): 41-47.

Ramaswamy, K. 2001. Organizational ownership, competitive intensity, and firm performance: An empirical study of the Indian manufacturing sector. Strategic Management Journal, 22(10): 989-998.

Ramaswamy, K. 2013. Gazprom: The ebb and flow of state patronage. Thunderbird Case Series A09-13-0004.

Ramaswamy, K., \& Von Glinow, M. 2000. Organizational performance following changes in ownership: Modelling postprivatization outcomes. Journal of Strategic Change, 9(5): 297-310.

Ramaswamy, K., Kroeck, K. G., \& Renforth, W. 1996. Measuring the degree of internationalization of a firm: A comment. Journal of International Business Studies, 27(1): 167-177.

Rodrik, D. 2007. One economics, many recipes: Globalization, institutions, and economic growth. Princeton, NJ: Princeton University Press.

Roth, K., \& O'Donnell, S. 1996. Foreign subsidiary compensation strategy: An agency theory perspective. Academy of Management journal, 39(3): 678-703.

Sauvant, K. P., \& Strauss, J. 2012. State-controlled entities control nearly US\$2 trillion in foreign assets. Perspectives on topical foreign direct investment issues by the Vale Columbia Center on Sustainable International Investment, No. 64, 2 April, http://www.vcc.columbia.edu/content/state-controlled-entitiescontrol-nearly-us-2-trillion-foreign-assets, accessed 18 April 2014.

Sauvant, K. P., Sachs, L., \& Schmit Jongbloed, W. P. F. (Eds) 2012. Sovereign investment: Concerns and policy reactions. New York: Oxford University Press.

Shapiro, D., \& Globerman, S. 2012. The international activities and impacts of state-owned enterprises. In K. P. Sauvant, L. Sachs, \& W. P. F. Schmit Jongbloed (Eds), Sovereign investment: Concerns and policy reactions. New York: Oxford University Press.

Shaver, J. M. 2013. Do we really need more entry mode studies? Journal of International Business Studies, 44(1): 23-27.

Shleifer, A., \& Vishny, R. 1998. The grabbing hand: Government pathologies and their cures. Cambridge, MA: Harvard University Press.

Stevens, G.V.G., \& Lipsey, R.E. 1992. Interactions between domestic and foreign investment. Journal of International Money and Finance, 11(1): 40-62.

Stopford, J. M., Strange, S., \& Henley, J. S. 1992. Rival States, rival firms: Competition for world market shares. New York: Cambridge University Press.

Tallman, S. B., \& Yip, G. S. 2001. Strategy and the multinational enterprise. In A. M. Rugman, \& T. L. Brewer (Eds), The Oxford Handbook of international business, 317-348. New York: Oxford University Press.

Teece, D. J. 1977. The multinational corporation and the resource transfer cost of technology transfer. Cambridge: Ballinger.

Trebat, T. J. 1985. Brazil's state-owned enterprises: A case study of the state as entrepreneur. New York: Cambridge University Press.

UNCTAD. 2011. World investment report 2011. Geneva: United Nations Conference on Trade and Development.
Joint Committee on Taxation. 1991. Factors affecting the international competitiveness of the United States. Washington DC: Government Printing Office, https://ia600408.us.archive.org/ 10/items/factorsaffecting691 unit/factorsaffecting691 unit.pdf, accessed 9 July 2014.

van Tulder, R., Lem, M., \& Geleynse, K. 2013. Doing business in Africa - A strategic guide for entrepreneurs. Utrecht: Berenschot.

van Tulder, R., \& van der Zwart, A. 2006. International businesssociety management: Linking corporate responsibility and globalization. New York: Routledge.

Vernon, R. 1979. The international aspects of state-owned enterprises. Journal of International Business Studies, 10(1): 7-14.

Vickers, J., \& Yarrow, G. 1988. Privatization: An economic analysis. Cambridge, MA: MIT Press.

Williamson, O. E. 1975. Markets and hierarchies: Analysis and antitrust implications. New York: Free Press.

Williamson, O. E. 1985. The economic institutions of capitalism. New York: Free Press.

Whitley, R. 1998. Internationalization and varieties of capitalism: The limited effects of cross-national coordination of economic activities on the nature of business systems. Review of International Political Economy, 5(3): 445-481.

Witt, M. A., \& Lewin, A. Y. 2007. Outward foreign direct investment as escape response to home country institutional constraints. Journal of International Business Studies, 38(4): 579-594.

Yergin, D., \& Stanislaw, J. 1998. The commanding heights. The battle for the world economy. New York: Touchstone.

\section{ABOUT THE AUTHORS}

Alvaro Cuervo-Cazurra is a Professor of International Business and Strategy at Northeastern University. He studies the internationalization of companies, with a special interest in emerging market multinationals, and governance issues, with a special interest in corruption. He is the Reviewing Editor of JIBS. He was awarded a PhD from MIT. The author can be reached at a.cuervocazurra@neu .edu.

Andrew Inkpen is the Seward Chair in Global Strategy at Thunderbird School of Global Management. He received his PhD from the Ivey School of Business. His research has focused on various aspects of international business and multinational companies, including alliance management, knowledge transfer and organizational trust. The author can be reached at andrew.inkpen@thunderbird.edu

Kannan Ramaswamy holds the William D. Hacker Chair Professorship in management at the Thunderbird School of Global Management. His research and teaching focuses on the challenges facing emerging market multinationals, management of MNCs, state ownership and business groups in developing countries. 
Aldo Musacchio is an associate professor of business at Harvard Business School, a visiting associate professor at the International Business School of Brandeis University and a Faculty Research Fellow at the National Bureau of Economic Research (NBER). He studies comparative corporate governance, state- owned enterprises and their internationalization, and the performance implications of different forms of state ownership and support of firms. He has a PhD from Stanford University. The author can be reached at aldom@brandeis.edu.

Accepted by John Cantwell, Editor-in-Chief, 12 July 2014. This paper has been with the authors for two revisions. 